\title{
PENGGUNAAN TENAGA KERJA ASING DALAM HUBUNGAN INDUSTRIAL
}

\author{
Oleh:
}

\author{
Mashudi ${ }^{1}$, Rochman Heri Dwi Prasetio ${ }^{2}$ \\ 1. Dosen Program Studi Ilmu Hukum, Fakultas Hukum, Universitas Gresik \\ 2. Mahasiswa Program Studi Ilmu Hukum, Fakultas Hukum, Universitas Gresik
}

\begin{abstract}
ABSTRAK
Kebutuhan dunia industri akan tenaga-tenaga ahli terampil semakin hari akan semakin dibutuhkan. Dalam hal tenaga ahli yang belum terpenuhi oleh Tenaga Kerja Indonesia, maka pelaku usaha dapat mempekerjakan Tenaga Kerja Asing (TKA). Dalam mempekerjakan TKA pemberi kerja wajib taat terhadap peraturan perundang-undangan yang berlaku. negara mempunyai kewenangan mengenai pengaturan-pengaturan dalam dunia ketenagakerjaan, salah satunya adalah pembatasan jabatanjabatan tertentu yang dapat diduduki oleh TKA. Terkait ketentuan perizinan penggunaan TKA dan penerapan sanksi terhadap pelanggaran penggunaan TKA sudah jelas dan tegas. Dengan kata lain peraturan tersebut cukup memadai karena dalam aturannya pemerintah terkait ketenagakerjaan dan keimigrasian telah melakukan sinergi yang baik. Terhadap berlakunya Masyarakat Ekonomi ASEAN, arus tenaga ahli dan terampil akan bebas keluar masuk wilayah Indonesia, dengan keadaan demikian selayaknya pemerintah perlu mengutamakan berjalannya ketentuan perundang-undangan tanpa mengesampingkan tujuan yang memberikan manfaat bagi kepentingan nasional.
\end{abstract}

Kata kunci : Tenaga Kerja Asing, Perizinan, Jabatan Tertentu

\section{A. PENDAHULUAN}

\subsection{Latar Belakang}

Di era globalisasi saat ini hubungan antar negara satu dengan negara yang lain semakin mudah dan terbuka. Hal tersebut juga didukung dengan perkembangan kemajuan teknologi informasi dan komunikasi yang membuat arus pergerakan barang, jasa dan sumber daya manusia semakin cepat. Dalam perkembangan industri juga diperlukan sumber daya manusia yang cukup. Perkembangan industri di Indonesia diharapkan dapat menyerap secara maksimal terhadap tenaga kerja Indonesia.
Semua orang baik warga negara Indonesia maupun warga negara asing memiliki kesempatan yang sama untuk memperoleh pekerjaan. Melihat kondisi perekonomian, kesepakatan internasional dan liberalisasi pasar bebas yang berkaitan dengan kepentingan nasional maka bukan tidak mungkin negara memberikan kesempatan bagi warga negara asing untuk memberikan kontribusi dalam dunia kerja Indonesia. Ada bagian tertentu dalam suatu perusahaan yang memang membutuhkan keterampilan khusus. Keterampilan khusus tersebut jika tenaga kerja lokal belum mumpuni, maka tidak ada cara lain selain menggunakan Tenaga Kerja Asing (TKA). 
TKA wajib patuh terhadap berbagai aturan yang mengatur ketentuanketentuan mengenai TKA ketika bekerja di wilayah Indonesia. Ketentuan mengenai arus lalu lintas warga negara asing yang datang ke Indonesia diatur dalam Undang-Undang Nomor 6 Tahun 2011 Tentang Keimigrasian dan ketentuan mengenai penggunaan tenaga kerja diatur dalam Undang-Undang Nomor 13 Tahun 2003 Tentang Ketenagakerjaan. Penggunaan TKA di Indonesia perlu adanya pembatasan baik dalam jumlah, waktu dan bidang-bidang tertentu yang dapat didudukinya. Pembatasan ini sesuai dengan aturan dalam Undang-Undang Nomor 13 Tahun 2003 Tentang Ketenagakerjaan. Hal ini bertujuan agar kehadiran TKA bukanlah merupakan suatu ancaman bagi tenaga kerja Indonesia namun dimaksudkan agar tenaga kerja Indonesia terpacu dan berkompetensi untuk lebih profesional dan selalu menambah keterampilan sehingga memiliki daya saing.

Memang tak semua jabatan dapat diduduki oleh TKA. Undang-Undang Nomor 13 Tahun 2003 Tentang Ketenagakerjaan telah mengaturnya dalam Pasal 42 ayat (4) yang berbunyi "Tenaga kerja asing dapat dipekerjakan di Indonesia dalam hubungan kerja untuk jabatan tertentu dan waktu tertentu". Kemudian Undang-Undang Nomor 6 Tahun 2011 Tentang Keimigrasian juga telah mengatur arus lalu lintas orang antar negara.

Tidak dapat dipungkiri dalam dunia industri alih teknologi dari negara- negara maju sangat diperlukan guna percepatan proses produksi barang maupun jasa. Berdasarkan uraian yang dipaparkan diatas, penulis tertarik untuk melakukan kajian lebih lanjut tentang penggunaan tenaga kerja asing dengan judul "Penggunaan tenaga kerja asing dalam hubungan industrial"

\subsection{Rumusan Masalah}

Berdasarkan latar belakang yang telah diuraikan tersebut dapat dirumuskan permasalahan sebagai berikut :

1. Bagaimana kedudukan tenaga kerja asing dalam hubungan industrial di Indonesia?

2. Bagaimana kewenangan pemerintah terhadap penggunaan tenaga kerja asing dalam hubungan industrial?

\section{B. TINJAUAN PUSTAKA}

Menurut Pasal 1 angka 13 UndangUndang Nomor 13 Tahun 2003 Tentang Ketenagakerjaan "Tenaga Kerja Asing (TKA) adalah warga negara asing pemegang visa dengan maksud bekerja di wilayah Indonesia". Sedangkan dalam Pasal 1 angka 9 UndangUndang Nomor 6 Tahun 2011 Tentang Keimigrasian"orang asing adalah orang yang bukan warga negara Indonesia”.

Tenaga kerja adalah setiap orang yang mampu melakukan pekerjaan guna menghasilkan barang/jasa baik untuk memenuhi kebutuhan sendiri maupun masyarakat.

Menurut Pasal 1 angka 1 UndangUndang Nomor 6 Tahun 2011 Tentang Keimigrasian, keimigrasian adalah ihwal lalu lintas orang yang masuk atau keluar wilayah 
Indonesia serta pengawasannya dalam rangka menjaga tegaknya kedaulatan negara.

Menurut Pasal 1 angka 16 UndangUndang Nomor 13 Tahun 2003 Tentang Ketenagakerjaan, hubungan industrial adalah suatu sistem hubungan yang terbentuk antara para pelaku dalam proses produksi barang dan/atau jasa yang terdiri atas unsur pengusaha, pekerja/buruh dan pemerintah yang didasarkan pada nilai-nilai Pancasila dan Undang-Undang Dasar Negara Republik Indonesia Tahun 1945.

\section{METODE PENELITIAN}

Tipe penelitian ini adalah penelitian hukum normatif. Penelitian hukum normatif adalah penelitian hukum yang meletakkan hukum hukum sebagai sebuah bangunan sistem norma. Sistem norma yang dimaksud adalah mengenai asas-asas, norma, kaidah dari peraturan perundangan, putusan pengadilan, perjanjian serta doktrin (ajaran). ${ }^{1}$

Metode pendekatan yang digunakan dalam penelitian ini adalah metode pendekatan perundang-undangan (statute approach), pendekatan historis atau sejarah (historical approach), pendekatan konseptual (conceptual approach) dan pendekatan komparatif atau perbandingan (comparative approach).

Dalam penelitian ini Penulis menggunakan sumber bahan hukum primer perundang-undangan dan peraturan dibawah undang-undang yang mempunyai keterkaitan dengan objek yang penulis teliti.

1 Mukti Fajar ND dan Yulianto Achmad, Dualisme Penelitian Hukum Normatif dan Empiris, Cet,. 2, Pustaka Pelajar, Yogyakarta, 2013, h. 34.
Bahan-bahan hukum sekunder berupa semua publikasi tentang hukum yang bukan merupakan dokumen-dokumen resmi. Publikasi tentang hukum meliputi buku-buku teks, kamus-kamus hukum, jurnal-jurnal hukum dan komentar atas putusan pengadilan. $^{2}$

Bahan hukum tersier juga merupakan bahan hukum yang dapat menjelaskan baik bahan hukum primer maupun bahan hukum sekunder, yang berupa kamus, ensiklopedi, leksikon dan lain-lain. ${ }^{3}$

Pengumpulan bahan hukum didasarkan pada keterkaitan serta keterpaduan informasi untuk memperoleh hasil penelitian yang lebih akurat. Kemudian melakukan penilaian terhadap berbagai bahan hukum baik primer, sekunder maupun tersier yang berhubungan penggunaan tenaga kerja dalam hubungan industrial.

\section{HASIL PENELITIAN DAN PEMBAHASAN}

Istilah hubungan industrial berasal dari industrial relation, merupakan perkembangan dari istilah hubungan perburuhan (labour relations atau labour management relations). Pada dasarnya masalah hubungan industrial mencakup aspek yang sangat luas, yakni aspek sosial budaya, psikologi, politik hukum dan hankamnas, sehingga hubungan industrial tidak hanya

\footnotetext{
2 Peter Mahmud Marzuki, Penelitian hukum, Cet. 12, Edisi Revisi, Prenada Media Group, Jakarta, 2016, h. 181.

3 Mukti Fajar ND dan Yulianto Achmad, Op.cit., h. 158.
} 
meliputi pengusaha dan pekerja, namun melibatkan pemerintah dan masyarakat. ${ }^{4}$

\section{Kedudukan tenaga kerja asing dalam hubungan industrial}

Pada prinsipnya orang asing, bahkan yang merupakan penduduk Indonesia mempunyai hak dan kewajiban yang berbeda dengan hak dan kewajiban warga negara Indonesia. Terhadap orang asing dikenakan pembatasan-pembatasan, khususnya masalah hak. $^{5}$

Dalam hal orang asing yang akan bekerja di wilayah Indonesia harus mengikuti ketentuan Undang-Undang Nomor 13 Tahun 2003 Tentang Ketenagakerjaan. Namun sebelum bekerja di wilayah Indonesia, orang asing tersebut selayaknya mempunyai dokumen perjalanan. Menurut Pasal 1 angka 19 Undang-Undang Nomor 6 Tahun 2011 Tentang Keimigrasian. Dokumen perjalanan adalah dokumen resmi yang dikeluarkan oleh pejabat berwenang dari suatu negara, perserikatan bangsa-bangsa, atau organisasi internasional lainnya untuk melakukan perjalanan antar negara yang memuat identitas pemegangnya.

Globalisasi telah menjadi fenomena yang tidak bisa dihindarkan dalam dunia bisnis. Perekonomian dunia semakin terbuka dan menjadi suatu kesatuan. Maraknya bisnis internasional terjadi sebagai akibatdari membaiknya infrastruktur, kondisi politik, dan sosial dunia. Hal ini ditandai dengan

4 Asri Wijayanti, Hukum Ketenagakerjaan Pasca Reformasi, Cet. 7, Sinar Grafika, Jakarta, 2017, h. 56.

5 Jazim Hamidi dan Charles Christian, Hukum Keimigrasian Bagi Orang Asing di Indonesia, Cet. 1, Sinar Grafika, Jakarta, 2015, h. 49. maraknya perusahaan yang beroperasi secara lintas negara. ${ }^{6}$

Pada Undang-Undang Nomor 13 Tahun 2003 Tentang Ketenagakerjaan telah mengatur penggunaan TKA pada bab VIII tentang Penggunaan TKA yakni Pasal 42 sampai dengan Pasal 49 Undang-Undang Nomor 13 Tahun 2003 Tentang Ketenagakerjaan.

Secara umum TKA juga dapat disebut sebagai pekerja migran. Pada tanggal 2 Mei 2012 pemerintah mengeluarkan Undang-Undang Nomor 6 Tahun 2012 Tentang Pengesahan International Convention on the Protection of the Right of All Migrant Workers and Members of Their Families (Konvensi Internasional Mengenai Perlindungan Hak-Hak Seluruh Pekerja Migran dan Anggota Keluarganya) pada Lembaran Negara Republik Indonesia Tahun 2012 Nomor 115.

Berdasarkan prinsip kedaulatan ini memungkinkan pemerintah untuk membuat regulasi terkait dengan lalu lintas orang asing yang masuk dari dan ke wilayahnya juga mengenai pengawasan orang asing di Indonesia. orang asing di Indonesia wajib untuk menghormati hukum positif yang berlaku. Berdasarkan prinsip kedaulatan negara memiliki hak lain berupa kekuasaan, yaitu: ${ }^{7}$

1. Kekuasaan eksekutif untuk mengendalikan persoalan domestik;

2. Kekuasaan untuk menerima dan mengusir orang asing;

6 Mila Badriyah, Manajemen Sumber Daya Manusia, Cet. 1, Pustaka Setia, Bandung, 2015, h.287.

7 Jazim Hamidi dan Charles Christian,Op.Cit., h. 8. 
3. Hak-hak istimewa perwakilan diplomatiknya di negara lain; dan

4. Yuridiksi penuh atas kejahatan yanng dilakukan dalam wilayahnya.

\section{Hak-hak tenaga kerja asing}

Hak-hak TKA menurut International Convention On The Protection Of The Rights Of All Migrant Workers And Member Their Families adalah sebagai berikut: ${ }^{8}$

1. Hak dasar untuk bebas dari diskriminasi;

2. Hak dasar untuk berpindah dan berkumpul dengan keluarganya;

3. Hak dasar untuk bebas dari kerja paksa;

4. Hak atas kebebasan berfikir, berkeyakinan dan beragama dan menjalankan agamanya;

5. Hak atas kebebasan menyampaikan pendapat;

6. Hak dasar untuk bekerja dan menerima upah yang menyumbang pada standar hidup yang sama;

7. Hak dasar persamaaan di depan hukum dan perlindungan hukum yang sama;

8. Hak dasar atas pembayaran yang sama dan pekerjaan yang sama;

9. Hak dasar atas perlindungan melawan pengusiran sewenang-wenang negara atas pekerjaan;

10. Hak dasar untuk pulang ke negara asal jika pekerja menginginkan;

11. Hak dasar atas persamaan standar hidup bagi kesehatan dan kesejahteraan dari pekerja dan anggota keluarganya;

12. Hak dasar atas kondisi aman pekerjaan yang aman dan kebersihan dan keamanan lingkungan pekerjaan;

8 Agustinus Edy Kristianto, Panduan Bantuan Hukum Di Indonesia, Cet. 1, Edisi Kedua, Yayasan Obor Indonesia, Jakarta, 2009, h. 265-266.
13. Hak dasar atas pembatasan yang layak dari jam kerja, istirahat dan waktu luang;

14. Hak dasar atas kebebasan berserikat dan bergabung dalam serikat pekerja;

15. Hak dasar atas perlindungan selama kehamilan dari pekerjaan yang berbahaya;

16. Hak dasar bagi anak-anak atas eksploitasi ekonomi dan pekerjaan yang membahayakan dirinya atau kesejahteraan dan pertumbuhannya;dan

17. Hak dasar dari anak-anak pekerja migran atas pendidikan.

\section{Kewajiban tenaga kerja asing}

Kewajiban warga negara pada dasarnya adalah hak negara. Negara sebagai organisasi kekuasaan memiliki sifat memaksa, memonopoli dan mencakup semua. Oleh karena itu merupakan hak negara untuk ditaati dan dilaksanakan hukum-hukum yang berlaku di negara tersebut. ${ }^{9}$

Berkaitan dengan dengan kewajibannya sebagai sebagai orang asing yang bekerja di Indonesia adalah sebagai berikut: ${ }^{10}$

1. Berkewajiban menaati semua peraturan yang berlaku di negara yang dia tempati atau berada.

2. Siap untuk di deportasi ke negara asalnya atau ke luar negeri karena habis masa izin tinggalnya dan termasuk pula masa perpanjangan izin tinggalnya.

3. Siap menentukan kewarganegaraannya jika dia menginginkan apabila telah melangsungkan perkawinan dengan warga negara Indonesia.

9 Winarno, Kewarganegaraan Indonesia Dari Sosiologis Menuju Yuridis, Alfabeta, Bandung, 2009, h. 98.

${ }^{10}$ Jazim Hamidi dan Charles

Christian, Op.Cit., h. 51-52. 
4. Sebagai tenaga kerja yang bekerja di Indonesia berkewajiban memberikan kemampuan keilmuan yang berhubungan dengan alih teknologi dan keterampilan pada perusahaan dimana ia bekerja

4. Pembatasan waktu dan jabatan bagi tenaga kerja asing

Ketentuan mengenai pembatasan waktu dan jabatan diatur dalam Pasal 42 ayat (4) Undang-Undang Nomor 13 Tahun 2003 Tentang Ketenagakerjaan yang berbunyi "Tenaga kerja asing dapat dipekerjakan di Indonesia hanya dalam hubungan kerja untuk jabatan tertentu dan waktu tertentu”. Hubungan kerja adalah hubungan antara pengusaha dengan pekerja/buruh berdasarkan perjanjian kerja, yang mempunyai unsur pekerjaan, upah dan perintah (Pasal 1 angka 15 Undang-Undang Nomor 13 Tahun 2003 Tentang Ketenagakerjaan). Jabatan tertentu berarti tidak semua jabatan dapat diduduki oleh TKA. Sedangkan waktu tertentu berarti dalam melakukan hubungan kerja di Indonesia, TKA memiliki batas waktu atau tidak untuk seterusnya.

$$
\text { Dalam Pasal } 46 \text { Undang-Undang }
$$

Nomor 13 Tahun 2003 Tentang
Ketenagakerjaan juga disebutkan secara spesifik mengenai jabatan-jabatan yang dilarang diduduki oleh TKA. Jabatan yang dimaksud adalah jabatan yang mengurusi personalia dan/atau jabatan-jabatan tertentu. Jabatan-jabatan tertentu tersebut diatur dalam Keputusan Menteri Tenaga Kerja dan Transmigrasi Nomor 40 Tahun 2012 Tentang Jabatan-Jabatan Tertentu Yang Dilarang Diduduki Tenaga Kerja Asing.

Berbagai jabatan tertentu dan waktu tertentu diatur dalam keputusan Menteri sebagai pelaksanaan Pasal 42 ayat

Undang-Undang Nomor 13 Tahun 2003

Tentang Ketenagakerjaan antara lain:

a. Keputusan Menteri Tenaga Kerja dan Transmigrasi Republik Indonesia Nomor Kep.247/Men/X/2011 Tentang Jabatan Yang Dapat Diduduki Oleh Tenaga Kerja Asing Pada Kategori Konstruksi

Mengatur klasifikasi dan nama jabatan yang dapat diduduki TKA. Namun, klasifikasi dan nama jabatan yang tidak tercantum dalam keputusan Menteri tersebut, Menteri terkait ketenagakerjaan dapat memberikan izin dengan terlebih dahulu meminta rekomendasi dari kementrian yang membidangi konstruksi. Jabatan yang dapat diduduki tersebut paling lama 5 (lima) tahun dan tidak dapat diperpanjang kecuali jabatan komisaris dan direktur sebagai pemilik modal.

b. Keputusan Menteri Tenaga Kerja dan Transmigrasi Republik Indonesia Nomor 462 Tahun 2012 Tentang Jabatan Yang Dapat Diduduki Oleh Tenaga Kerja Asing Pada Kategori Jasa Pendidikan.

Pada peraturan tersebut memuat jabatan-jabatan yang dapat diduduki TKA, namun Menteri terkait ketenagakerjaan juga dapat memberikan izin dengan terlebih dahulu meminta rekomendasi dari kementrian yang membidangi pendidikan. Jabatan yang dapat diduduki tersebut paling lama 5 (lima) tahun dan tidak dapat diperpanjang kecuali jabatan komisaris dan direktur sebagai pemilik modal.

c. Keputusan Menteri Tenaga Kerja dan Transmigrasi Republik Indonesia Nomor 463 Tahun 2012 Tentang Jabatan Yang Dapat Diduduki Oleh Tenaga Kerja Asing 
Pada Kategori Industri Pengolahan Golongan Pokok Industri Bahan Kimia Dan Barang Dari Bahan Kimia.

Pada peraturan tersebut memuat jabatan-jabatan yang dapat diduduki TKA, namun Menteri terkait ketenagakerjaan dapat memberikan izin dengan terlebih dahulu meminta rekomendasi dari kementrian yang membidangi perindustrian. Jabatan yang dapat diduduki tersebut paling lama 5 (lima) tahun dan tidak dapat diperpanjang kecuali jabatan komisaris dan direktur sebagai pemilik modal.

d. Keputusan Menteri Tenaga Kerja dan Transmigrasi Republik Indonesia Nomor 464 Tahun 2012 Tentang Jabatan Yang Dapat Diduduki Oleh Tenaga Kerja Asing Pada Kategori Perdagangan Besar Dan Eceran Serta Reparasi dan Perawatan Mobil Dan Sepeda Motor.

Peraturan tersebut mengatur klasifikasi dan nama jabatan yang dapat diduduki TKA. Namun, klasifikasi dan nama jabatan yang tidak tercantum dalam keputusan Menteri tersebut, Menteri terkait ketenagakerjaan dapat memberikan izin dengan terlebih dahulu meminta rekomendasi dari kementrian yang membidangi perdagangan. Jabatan yang dapat diduduki tersebut paling lama 5 (lima) tahun dan tidak dapat diperpanjang kecuali jabatan komisaris dan direktur sebagai pemilik modal.

e. Keputusan Menteri Tenaga Kerja dan Transmigrasi Republik Indonesia Nomor 707 Tahun 2012 Tentang Jabatan Yang Dapat Diduduki Oleh Tenaga Kerja Asing Pada Kategori Transportasi Dan
Pergudangan Golongan Pokok Angkutan Udara.

Pada peraturan tersebut mengatur klasifikasi dan nama jabatan yang dapat diduduki TKA. Namun, klasifikasi dan nama jabatan yang tidak tercantum dalam keputusan Menteri tersebut, Menteri terkait ketenagakerjaan dapat memberikan izin dengan terlebih dahulu meminta rekomendasi dari kementrian yang membidangi transportasi. Jabatan yang dapat diduduki tersebut paling lama 5 (lima) tahun dan tidak dapat diperpanjang kecuali jabatan komisaris dan direktur sebagai pemilik modal.

f. Keputusan Menteri Tenaga Kerja dan Transmigrasi Republik Indonesia Nomor 354 Tahun 2013 Tentang Jabatan Yang Dapat Diduduki Oleh Tenaga Kerja Asing Pada Kategori Industri Pengolahan Golongan Pokok Industri Minuman.

Pada peraturan tersebut mengatur klasifikasi dan nama jabatan yang dapat diduduki TKA. Namun, klasifikasi dan nama jabatan yang tidak tercantum dalam keputusan Menteri tersebut, Menteri terkait ketenagakerjaan dapat memberikan izin dengan terlebih dahulu meminta rekomendasi dari kementrian yang membidangi perindustrian. Keputusan Menteri tersebut tidak mengatur waktu maksimal jabatan yang dapat diduduki oleh TKA.

g. Keputusan Menteri Tenaga Kerja dan Transmigrasi Republik Indonesia Nomor 355 Tahun 2013 Tentang Jabatan Yang Dapat Diduduki Oleh Tenaga Kerja Asing Pada Kategori Pengadaan Air, Pengelolaan Sampah Dan Daur Ulang, Pembuangan 
dan Pembersihan Limbah Dan Sampah Golongan Pokok Pengelolaan Limbah.

Pada peraturan tersebut mengatur klasifikasi dan nama jabatan yang dapat diduduki TKA. Namun, klasifikasi dan nama jabatan yang tidak tercantum dalam keputusan Menteri tersebut, Menteri terkait ketenagakerjaan dapat memberikan izin dengan terlebih dahulu meminta rekomendasi dari kementrian yang membidangi lingkungan hidup. Keputusan Menteri tersebut tidak mengatur waktu maksimal jabatan yang dapat diduduki oleh TKA.

h. Keputusan Menteri Tenaga Kerja dan Transmigrasi Republik Indonesia Nomor 356 Tahun 2013 Tentang Jabatan Yang Dapat Diduduki Oleh Tenaga Kerja Asing Pada Kategori Industri Pengolahan Golongan Pokok Industri Tekstil.

Pada peraturan tersebut mengatur klasifikasi dan nama jabatan yang dapat diduduki TKA. Namun, klasifikasi dan nama jabatan yang tidak tercantum dalam keputusan Menteri tersebut, Menteri terkait ketenagakerjaan dapat memberikan izin dengan terlebih dahulu meminta rekomendasi dari kementrian yang membidangi perindustrian. Keputusan Menteri tersebut tidak mengatur waktu maksimal jabatan yang dapat diduduki oleh TKA.

i. Keputusan Menteri Tenaga Kerja dan Transmigrasi Republik Indonesia Nomor 357 Tahun 2013 Tentang Jabatan Yang Dapat Diduduki Oleh Tenaga Kerja Asing Pada Kategori Industri Pengolahan Golongan Pokok Industri Pakaian Jadi.
Pada peraturan tersebut mengatur klasifikasi dan nama jabatan yang dapat diduduki TKA. Namun, klasifikasi dan nama jabatan yang tidak tercantum dalam keputusan Menteri tersebut, Menteri terkait ketenagakerjaan dapat memberikan izin dengan terlebih dahulu meminta rekomendasi dari kementrian yang membidangi perindustrian. Keputusan Menteri tersebut tidak mengatur waktu maksimal jabatan yang dapat diduduki oleh TKA.

j. Keputusan Menteri Tenaga Kerja dan Transmigrasi Republik Indonesia Nomor 358 Tahun 2013 Tentang Jabatan Yang Dapat Diduduki Oleh Tenaga Kerja Asing Pada Kategori Industri Pengolahan Golongan Pokok Industri Makanan.

Pada peraturan tersebut mengatur klasifikasi dan nama jabatan yang dapat diduduki TKA. Namun, klasifikasi dan nama jabatan yang tidak tercantum dalam keputusan Menteri tersebut, Menteri terkait ketenagakerjaan dapat memberikan izin dengan terlebih dahulu meminta rekomendasi dari kementrian yang membidangi perindustrian. Keputusan Menteri tersebut tidak mengatur waktu maksimal jabatan yang dapat diduduki oleh TKA.

k. Keputusan Menteri Tenaga Kerja dan Transmigrasi Republik Indonesia Nomor 359 Tahun 2013 Tentang Jabatan Yang Dapat Diduduki Oleh Tenaga Kerja Asing Pada Kategori Industri Pengolahan Golongan Pokok Industri Barang Bukan Logam Bukan Mesin Dan Peralatannya.

Pada peraturan tersebut mengatur klasifikasi dan nama jabatan yang dapat 
diduduki TKA. Namun, klasifikasi dan nama jabatan yang tidak tercantum dalam keputusan Menteri tersebut, Menteri terkait ketenagakerjaan dapat memberikan izin dengan terlebih dahulu meminta rekomendasi dari kementrian yang membidangi perindustrian. Keputusan Menteri tersebut tidak mengatur waktu maksimal yang dapat diduduki TKA.

Dari berbagai Keputusan Menteri terkait jabatan yang dapat diduduki oleh TKA dan lamanya waktu sepenuhnya belum memiliki kepastian hukum karena beberapa keputusan tidak mengatur lamanya waktu maksimal yang dapat diduduki TKA serta terjadi pelimpahan wewenang antar kementerian walaupun jabatan yang dimaksud sudah dimuat dalam lampiran keputusan.

\section{Perizinan penggunaan tenaga kerja asing}

Dalam hukum ketenagakerjaan tata cara penggunaan TKA diatur dalam Peraturan Menteri Ketenagakerjaan Nomor 10 Tahun 2018 Tentang Tata Cara Penggunaan Tenaga Kerja Asing sebagai pelaksanaan Pasal 43 ayat (4) Undang-Undang Nomor 13 Tahun 2003 Tentang Ketenagakerjaan. Kemudian untuk mendukung perekonomian nasional dan perluasan kesempatan kerja melalui peningkatan investasi pemerintah mengeluarkan Peraturan Presiden Nomor 20 Tahun 2018 Tentang Penggunaan Tenaga Kerja Asing sebagai pelaksanaan Pasal 49 Undang-Undang Nomor 13 Tahun 2003 Tentang Ketenagakerjaan.

Peraturan tersebut terbilang sangat baru mengingat penulis juga menyelesaikan penelitian ini pada tahun 2018. Sebelumnya pelaksanaan pasal 43 ayat (4) Undang-Undang Nomor 13 Tahun 2003 Tentang Ketenagakerjaan diatur dalam Peraturan Menteri Ketenagakerjaan Nomor 35 Tahun 2015 Tentang Perubahan Atas Peraturan Menteri Ketenagakerjaan Nomor 16 Tahun 2015 Tentang Tata Cara Penggunaan Tenaga Kerja Asing. Peraturan Menteri Ketenagakerjaan Nomor 10 Tahun 2018 Tentang Tata Cara Penggunaan Tenaga Kerja Asing merupakan peraturan yang menyesuaikan dengan perkembangan ketenagakerjaan pada dewasa ini agar memberikan manfaat bagi kepentingan nasional.

Menurut Pasal 5 Peraturan Menteri Ketenagakerjaan Nomor 10 Tahun 2018 Tentang Tata Cara Penggunaan Tenaga Kerja Asing, pemberi kerja sebelum mempekerjakan TKA, TKA tersebut wajib memenuhi kualifikasi sebagai berikut:

a. Memiliki pendidikan yang sesuai dengan kualifikasi jabatan yang akan diduduki oleh TKA.

b. Memiliki sertifikat kompetensi atau memiliki pengalaman kerja paling sedikit 5 (lima) tahun yang sesuai denga kualifikasi jabatan yang akan diduduki TKA.

c. Mengalihkan keahliannya kepada tenaga kerja pendamping.

d. Memiliki nomor pokok wajib pajak bagi TKA yang sudah bekerja lebih dari 6 (enam) bulan; dan

e. Memiliki Itas (izin tinggal terbatas) untuk bekerja yang diterbitkan oleh instansi yang berwenang.

Pemberi kerja kecuali orang perorangan dalam mempekerjakan TKA wajib memiliki kualifikasi sebagaimana Pasal 5 
Peraturan Menteri Ketenagakerjaan Nomor 10 Tahun 2018 Tentang Penggunaan Tenaga Kerja Asing. kemudian memiliki RPTKA, membayar DKP-TKA dan lain-lain sebagaimana Pasal 4 ayat (4) Peraturan Menteri Ketenagakerjaan Nomor 10 Tahun 2018 Tentang Penggunaan Tenaga Kerja Asing. Pengesahan RPTKA dilakukan sebagaimana Pasal 13 ayat (1) Peraturan Menteri Ketenagakerjaan Nomor 10 Tahun 2018 Tentang Penggunaan Tenaga Kerja Asing untuk memperoleh notifikasi oleh Dirjen.

Menurut Pasal 1 angka 20 Peraturan Menteri Ketenagakerjaan Nomor 10 Tahun 2018 Tentang Tata Cara Penggunaan Tenaga Kerja Asing.Notifikasi adalah persetujuan penggunaan TKA yang diterbitkan oleh Direktur Jenderal Pembinaan Dan Penempatan Tenaga Kerja Dan Perluasan Kesempatan Kerja Sebagai Dasar Penerbitan Itas.

\section{Pengawasan dan sanksi terkait penggunaan tenaga kerja asing \\ Menurut Pasal 176 Undang-Undang} Nomor 13 Tahun 2003 Tentang Ketenagakerjaan. pengawasan ketenagakerjaan dilakukan oleh pegawai pengawas ketenagakerjaan yangmempunyai kompetensi dan independen guna menjamin pelaksanaan peraturan perundang-undangan ketenagakerjaan.

Dalam ketentuan Undang-Undang Nomor 13 Tahun 2003 Tentang Ketenagakerjaan, Pelanggaran atas ketentuan Pasal 41 ayat (1) dan ayat (2) Undang-Undang Nomor 13 Tahun 2003 Tentang Ketenagakerjaan merupakan tindak pidana kejahatan. $^{11}$ Sedangkan pelanggaran atas ketentuan Pasal 44 ayat (1) dan Pasal 45 ayat (1) Undang-Undang Nomor 13 Tahun 2003 Tentang Ketenagakerjaan merupakan tindak pidana pelanggaran. ${ }^{12}$

\section{E. KESIMPULAN DAN SARAN}

1. Kesimpulan

1. Meskipun dalam International Convention on the Protection of the Right of All Migrant Workers and Members of Their Families (Konvensi Internasional Mengenai Perlindungan Hak-Hak Seluruh Pekerja Migran dan Anggota Keluarganya) yang disahkan oleh Undang-Undang Nomor 6 Tahun 2012 yang mengatur hakhak pekerja Migran di Indonesia, namun pemerintah berwenang mengatur pekerja migran atau TKA yang bekerja di wilayah Indonesia dengan menganut ketentuan di bidang ketenagakerjaan serta peraturan perundang-undangan lainnya karena pemerintah berwenang mengatur masalah ketenagakerjaan di dalam negaranya agar terjadi ketertiban nasional.

2. Kewenangan pemerintah dalam penggunaan TKA, dapat disimpulkan sebagai berikut:

a. Pengaturan berbagai jabatan tertentu dan waktu tertentu diatur dalam keputusan Menteri sebagai pelakasanaan Pasal 42 ayat (5) Undang-Undang Nomor 13 Tahun 2003 Tentang Ketenagakerjaan, kurang

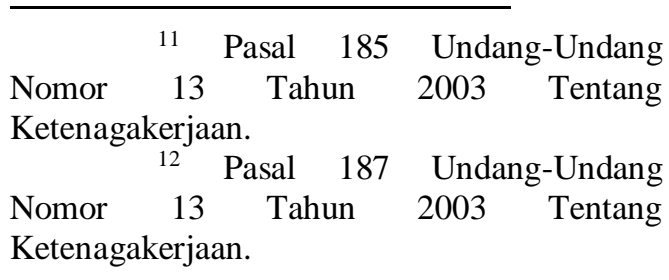


memiliki kepastian hukum karena dalam beberapa keputusan Menteri sebagai pelakasanaan Pasal 42 ayat (5) Undang-Undang Nomor 13 Tahun 2003 Tentang Ketenagakerjaan masih ada pelimpahan wewenang antar kementerian serta tidak mengatur maksimal lamanya jabatan yang dapat diduduki oleh TKA.

b. Perizinan penggunaan TKA pada Undang-Undang Nomor 6 Tahun 2011 Tentang Keimigrasian maupun Undang-Undang Nomor 13 Tahun 2003 Tentang Ketenagakerjaan serta berbagai peraturan pelaksanaan terutama pada Peraturan Presiden Nomor 20 Tahun 2018 Tentang Penggunaan Tenaga Kerja Asing dan Peraturan Menteri Ketenagakerjaan Nomor 10 Tahun 2018 Tentang Tata Cara Penggunaan Tenaga Kerja Asing sudah cukup memadai karena dalam peraturan pelaksanaan sudah terjadi sinergi antara pemerintah di bidang ketenagakerjaan dan di bidang keimigrasian.

c. Secara normatif terkait pengawasan dan sanksi terhadap penyalahgunaan penggunaan TKA sudah cukup jelas dan tegas tekait sanksi yang akan dikenakan baik jenis sanksi administratif, pidana pelanggaran maupun pidana kejahatan.

\section{Saran}

1. Pemberi kerja TKA selayaknya untuk memberikan pelatihan berbahasa Indonesia dan pengertian terkait peraturan perundang-undangan yang berlaku di Indonesia agar dalam bertindak dalam kehidupan sehari-hari TKA setidaknya mengerti peraturan di Indonesia.Pemerintah perlu mengkaji ketentuan mengenai pelimpahan wewenang yang mengatur jabatan yang boleh diduduki oleh TKA. Penulis berpendapat agar kewenangan sepenuhnya dilakukan oleh pemerintah yang mengatur bidang ketenagakerjaan sepanjang memenuhi kualifikasi yang ditetapkan, masa kerja yang jelas dan dengan memperhatikan penuh kondisi pasar kerja dalam negeri.

2. Terkait perizinan yang sudah cukup memadai baiknya semua pihak baik pekerja/buruh, pengusaha/pemberi kerja dan pemerintah bersama-sama melakukan pengawasan terkait jalannya peraturan perundang-undangan agar terjadi hubungan industrial yang harmonis.

\section{DAFTAR PUSTAKA}

\section{Daftar Buku}

Adolf, Huala, Aspek-Aspek Negara Dalam Hukum Internasional, PT. Raja Grafindo Persada, Jakarta, 2002.

Badriyah, Mila, Manajemen Sumber Daya Manusia, Cet. 1, Pustaka Setia, Bandung, 2015.

Fahrojih, Ikhwan, Hukum Perburuhan, Setara Press, Malang, 2016

Fajar ND, Mukti dan Yulianto Achmad, Dualisme Penelitian Hukum Normatif dan Empiris, Cet,. 2, Pustaka Pelajar, Yogyakarta, 2013.

Hamidi, Jazim dan Charles Christian, Hukum Keimigrasian Bagi Orang Asing di Indonesia, Cet. 1, Sinar Grafika, Jakarta, 2015

Husni, Lalu, Pengantar Hukum Ketenagakerjaan, Cet. 14, Edisi revisi, Rajawali Pers, Jakarta, 2016. 
Khakim, Abdul, Dasar-dasar hukum ketenagakerjaan, Cet. 1, Edisi IV, Citra Aditya Bakti, Bandung, 2014.

Kristianto, Agustinus Edy, Panduan Bantuan Hukum Di Indonesia, Cet. 1, Edisi Kedua, Yayasan Obor Indonesia, Jakarta, 2009.

Kusumaatmadja, Mochtar dan Etty R. Agoes, Pengantar Hukum Internasional, Edisi 2, Alumni, Bandung, 2013.

Kusumo, Bambang S Widagdo, Mengurai benang kusut hukum perburuhan, CV Annadia, Sidoarjo, 2006.

Marzuki, Peter Mahmud, Penelitian hukum, Cet. 12, Edisi revisi, Prenada Media Group, Jakarta, 2016.

Soepomo, Iman, Pengantar Hukum Perburuhan, Cet. 11, Djambatan, Jakarta, 1995.

Supramono, Gatot, Hukum orang asing di Indonesia, Sinar Grafika, Jakarta, 2014.

Wijayanti, Asri, Hukum Ketenagakerjaan Pasca Reformasi, Cet. 7, Sinar Grafika, Jakarta, 2017.

Winarno, Kewarganegaraan Indonesia Dari Sosiologis Menuju Yuridis, Alfabeta, Bandung, 2009.

\section{Perundang-undangan}

Undang-Undang Dasar Negara Republik Indonesia Tahun 1945.

Undang-Undang Republik Indonesia Nomor 13 Tahun $2003 \quad$ Tentang Ketenagakerjaan.

Undang-Undang Republik Indonesia Nomor 6 Tahun 2011 Tentang Keimigrasian.

Undang-Undang Nomor 6 Tahun 2012 Tentang Pengesahan International Convention on the Protection of the Right of All Migrant Workers and Members of Their Families (Konvensi Internasional Mengenai Perlindungan Hak-Hak Seluruh Pekerja Migran dan Anggota Keluarganya)
Peraturan Presiden Nomor 20 Tahun 2018 Tentang Penggunaan Tenaga Kerja Asing.

Keputusan Presiden Nomor Republik Indonesia Nomor 37 Tahun 2014 Tentang Komite Nasional Persiapan Pelaksanaan Masyarakat Ekonomi ASEAN

Peraturan Menteri Ketenagakerjaan Republik Indonesia Nomor 10 Tahun 2018 tentang Tata Cara Penggunaan Tenaga Kerja Asing.

Keputusan Menteri Tenaga Kerja dan Transmigrasi Republik Indonesia Nomor Kep.247/Men/X/2011 Tentang Jabatan Yang Dapat Diduduki Oleh Tenaga Kerja Asing Pada Kategori Konstruksi.

Keputusan Menteri Tenaga Kerja dan Transmigrasi Republik Indonesia Nomor 462 Tahun 2012 Tentang Jabatan Yang Dapat Diduduki Oleh Tenaga Kerja Asing Pada Kategori Jasa Pendidikan.

Keputusan Menteri Tenaga Kerja dan Transmigrasi Republik Indonesia Nomor 463 Tahun 2012 Tentang Jabatan Yang Dapat Diduduki Oleh Tenaga Kerja Asing Pada Kategori Industri Pengolahan Golongan Pokok Industri Bahan Kimia Dan Barang Dari Bahan Kimia.

Keputusan Menteri Tenaga Kerja dan Transmigrasi Republik Indonesia Nomor 464 Tahun 2012 Tentang Jabatan Yang Dapat Diduduki Oleh Tenaga Kerja Asing Pada Kategori Perdagangan Besar Dan Eceran Serta Reparasi dan Perawatan Mobil Dan Sepeda Motor.

Keputusan Menteri Tenaga Kerja dan Transmigrasi Republik Indonesia Nomor 707 Tahun 2012 Tentang Jabatan Yang Dapat Diduduki Oleh Tenaga Kerja Asing Pada Kategori Transportasi Dan Pergudangan Golongan Pokok Angkutan Udara.

Keputusan Menteri Tenaga Kerja dan Transmigrasi Republik Indonesia Nomor 34 Tahun 2013 Tentang Jabatan Yang Dapat Diduduki Oleh 
Tenaga Kerja Asing Pada Kategori Industri Pengolahan Golongan Pokok Industri Minuman.

Keputusan Menteri Tenaga Kerja dan Transmigrasi Republik Indonesia Nomor 355 Tahun 2013 Tentang Jabatan Yang Dapat Diduduki Oleh Tenaga Kerja Asing Pada Kategori Pengadaan Air, Pengelolaan Sampah Dan Daur Ulang, Pembuangan dan Pembersihan Limbah Dan Sampah Golongan Pokok Pengelolaan Limbah.

Keputusan Menteri Tenaga Kerja dan Transmigrasi Republik Indonesia Nomor 356 Tahun 2013 Tentang Jabatan Yang Dapat Diduduki Oleh Tenaga Kerja Asing Pada Kategori Industri Pengolahan Golongan Pokok Industri Tekstil.

Keputusan Menteri Tenaga Kerja dan Transmigrasi Republik Indonesia
Nomor 357 Tahun 2013 Tentang Jabatan Yang Dapat Diduduki Oleh Tenaga Kerja Asing Pada Kategori Industri Pengolahan Golongan Pokok Industri Pakaian Jadi.

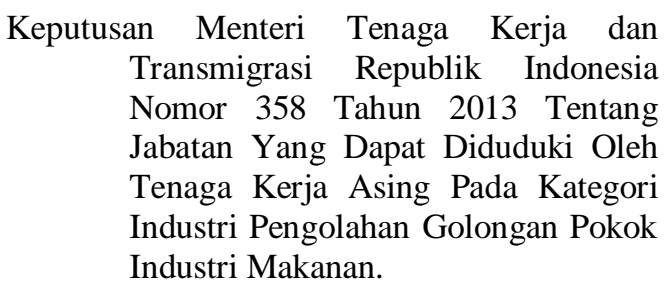

Keputusan Menteri Tenaga Kerja dan Transmigrasi Republik Indonesia Nomor 359 Tahun 2013 Tentang Jabatan Yang Dapat Diduduki Oleh Tenaga Kerja Asing Pada Kategori Industri Pengolahan Golongan Pokok Industri Barang Bukan Logam Bukan Mesin Dan Peralatannya. 